\title{
5-Lipoxygenase modulates colitis through the regulation of adhesion molecule expression and neutrophil migration
}

\author{
Salvatore Cuzzocrea ${ }^{1}$, Antonietta Rossi ${ }^{2}$, Emanuela Mazzon $^{3}$, Rosanna Di Paola ${ }^{1}$, \\ Tiziana Genovese ${ }^{1}$, Carmelo Muià ${ }^{1}$, Achille P Caputi ${ }^{1}$ and Lidia Sautebin ${ }^{2}$ \\ ${ }^{1}$ Department of Clinical and Experimental Medicine and Pharmacology, University of Messina Torre \\ Biologica, Policlinico Universitario, Messina, Italy; ${ }^{2}$ Department of Experimental Pharmacology, University \\ of Naples "Federico II", Napoli, Italy and ${ }^{3}$ Department of Biomorphology, School of Medicine, University \\ of Messina, Messina, Italy
}

\begin{abstract}
Leukotrienes play a part in inflammatory response. The unique role of the enzyme 5-lipoxygenase (5-LO) in the production of leukotrienes makes it as therapeutic target for inflammatory conditions like inflammatory bowel disease (IBD). In the present study, by comparing the responses in wild-type mice (5-LOWT) and mice lacking the 5-lipoxygenase (5-LOKO), we investigated the role played by this enzyme in the development of experimental colitis. To address this question, we used an experimental model of colitis, induced by dinitrobenzene sulfonic acid (DNBS). When compared to DNBS-treated 5-LOWT mice, DNBS-treated 5-LOKO mice experienced a reduced rate of the extent and severity of the histological signs of colon injury. After administration of DNBS 5-LOWT mice showed hemorrhagic diarrhea, weight loss and large areas of necrosis in the mucosa of the colon. Neutrophil infiltration was associated with the expression of ICAM-1, VCAM-1, P-selectin, E-selectin that were mainly localized around vessels. Absence of a functional 5-LO resulted in a significant reduction of all the above-described parameters. In particular, we have observed a significant reduction of: (i) the degree of colon injury, (ii) the rise in myeloperoxidase (MPO) activity (mucosa), (iii) the increase in staining (immunohistochemistry) for ICAM-1, VCAM-1, P-selectin, E-selectin caused by DNBS in the colon. Similarly, the treatment of 5-LOWT with zileuton $(50 \mathrm{mg} / \mathrm{kg}$ per os twice a day) resulted in a significant reduction of all the above-described parameters. In addition, in in vitro study a significantly reduced chemotactic response to IL-8 was observed in peripheral blood leukocytes from 5-LOKO in comparison to 5-LOWT polymorphonuclear leukocyte. Similar results were obtained when we analyzed the chemotactic response of 5 -LOWT cell incubated for $15 \mathrm{~min}$ with zileuton $(50 \mu \mathrm{g} / \mathrm{ml})$. Taken together, our results clearly demonstrate that 5-LO modulates neutrophil infiltration in experimental colitis through the expression of adhesion molecules.
\end{abstract}

Laboratory Investigation (2005) 85, 808-822, advance online publication, 11 April 2005; doi:10.1038/labinvest.3700276

Keywords: 5-lipoxygenase; dinitrobenzene sulfonic acid; neutrophil infiltration; adhesion molecules

The inflammatory bowel diseases (IBD), Crohn's disease, and ulcerative colitis have become important health problems in recent years. With an actual prevalence of 200-500 per 100000 people in Western countries and an incidence of about 20 per 100000 people, the prevalence of these patho-

Correspondence: Professor S Cuzzocrea, PhD, Department of Clinical and Experimental Medicine and Pharmacology, University of Messina, School of Medicine, University of Messina, via C. Valeria, Torre Biologica, Policlinico Universitario, 98123 Messina, Italy.

E-mail: salvator@unime.it

Received 29 November 2004; revised 1 February 2005; accepted 18 February 2005; published online 11 April 2005 logies in high incidence areas almost doubles every 10 years. Indeed, these are diseases of a lifetime, affecting people at a young age. In the last decade, it has been observed a shift towards more Crohn's disease in areas with high incidence of IBD, and IBD has tended to occur at all ages. While this disease has a worldwide distribution, its pathogenesis is not clearly understood. ${ }^{1}$ During the last decade, several experimental animal models of inflammatory bowel diseases have been developed to define the different components of the pathophysiological processes that characterize these disorders. ${ }^{2-5}$ Among these models, the intrarectal administration of 2,4-dinitrobenzene sulfonic acid (DNBS) has been extensively used to study the mechanisms of colonic 
inflammation and to test anti-inflammatory drugs. ${ }^{6,7}$ Infections, trauma, or chemical insults are believed to induce several cellular reactions, which eventually lead to an inflammatory status of the colon. At the same time, however, protective mechanisms aimed at preventing the pathological outcome of pro-inflammatory insults are also induced. Hence, the overall balance between pro- and anti-inflammatory mechanisms is likely to determine the progression and severity of colitis. A better understanding of intrinsic mechanisms that protect against inflammation would provide an effective starting point for development of novel therapeutic treatments.

Leukotrienes are potent lipid mediators of inflammatory responses and have been implicated in the pathophysiology of both acute and chronic inflammatory diseases including asthma, arthritis, psoriasis, and inflammatory bowel diseases. ${ }^{8}$ The production of all leukotrienes from arachidonic acid (AA) is dependent on the expression of arachidonate 5-lipoxygenase (5-LO).

The conversion of AA to leukotriene A4 (LTA4) by the enzyme 5-LO is the first step in the synthesis of all leukotrienes. LTA4 can either be converted to leukotriene B4 (LTB4) by LTA4 hydrolase or conjugated with reduced glutathione by LTC4 synthase to form leukotriene C4 (LTC4). The biologic activities of leukotrienes suggest that they are mediators of acute inflammatory and immediate hypersensitivity responses. Peptidyl leukotrienes, which are released by leukocytes in response to inflammatory and immunologic stimuli, cause contraction of endothelial cells, resulting in increased permeability of postcapillary venules. ${ }^{9}$ The peptidyl leukotrienes are also potent bronchoconstrictors ${ }^{10}$ and continue to be considered important mediators of allergic diseases of the airways. ${ }^{11,12}$ Therefore, both the peptidyl leukotrienes and LTB4 increase the adhesion of leukocytes to endothelial cells. ${ }^{13}$ In the last few years, various studies have gained substantial insight into the importance of specific adhesion molecules and mediators in the following processes that finally result in the recruitment of polymorphonuclear leukocytes (PMNs) at a specific site of inflammation: (1) margination, capture and rolling on the vascular endothelium, (2) activation and firm adhesion, (3) diapedesis through gaps between endothelial cells in postcapillary venules, and (4) finally, migration along a gradient of chemokines. Activated PMNs, therefore, play a crucial role in the destruction of foreign antigens and the breakdown and remodelling of injured tissue. Leukocyte-endothelial interactions involve a complex interplay among adhesion glycoproteins (ie integrins, members of the immunoglobulin superfamily, and selectins). One member of the selectin family, P-selectin, is rapidly translocated from the Weibel-Palade bodies to the endothelial cell surface upon activation of endothelial cells with thrombin, histamine, hypoxia-reoxygenation, or oxygen-derived free radicals. ${ }^{14,15}$ P-selectin promotes rolling of leukocytes on the endothelium. E-selectin is expressed on inflamed endothelial cells in response to treatment with inflammatory cytokines. ${ }^{16}$ Intravital microscopic experiments have shown that its function in mediating leukocyte rolling is largely redundant with that of P-selectin. ${ }^{17-19}$ Consequently, E-selectin-deficient mice have only a subtle defect in leukocyte rolling as shown by much faster rolling velocities in these mice. ${ }^{19}$ In addition to mediating leukocyte rolling, E-selectin participates in the conversion of rolling to firm adhesion. E-selectin-deficient mice have a reduced number of firmly adherent leukocytes in response to local chemoattractant ${ }^{20}$ or cytokine stimulation. $^{21}$ This defect may be related to the more rapid rolling velocities in the absence of $\mathrm{E}$ selectin. E-selectin is expressed in skin microvessels under baseline conditions, ${ }^{22}$ and there is some evidence that E-selectin is of particular importance in skin inflammation, because it supports the recruitment of skin-specific $\mathrm{T}$ lymphocytes. ${ }^{23}$ The rolling of leukocytes is the first step in the interactions of leukocytes with the endothelium and facilitates the activation and adherence of PMNs. ${ }^{24}$ The firm adhesion of PMNs to the endothelium, however, is a complex phenomenon, which also involves other endothelium-based adhesion molecules. In fact, endothelial adhesion molecules are considered to play a pivotal role in the localization and development of an inflammatory reaction. ${ }^{25}$ Intercellular adhesion molecules (ICAM-1) is an adhesion molecule normally expressed at a low basal level, but its expression can be enhanced by various inflammatory mediators such as IL-1 and TNF- $\alpha .{ }^{26}$ Vascular cell adhesion molecule-1 (VCAM1) contains six or seven immunoglobulin domains and is expressed on both large and small vessels only after the endothelial cells are stimulated by cytokines. Primarily, VCAM-1 is an endothelial ligand for VLA-4 (Very Late Antigen-1 or $\alpha_{4} \beta_{1}$ ) of the $\beta_{1}$ subfamily of integrins and for integrin $\alpha_{4} \beta_{7}$. VCAM-1 promotes the adhesion of lymphocytes, monocytes, eosinophils, and basophils. Interestingly, certain melanoma cells can use VCAM-1 to adhere to the endothelium, and VCAM-1 may participate in monocyte recruitment to atherosclerotic sites. The crucial role of adhesion molecules in inflammatory disorders ${ }^{27,28}$ makes them interesting targets for drug development. Pioneering studies with antiadhesion strategies have been undertaken in asthma, where antagonists of Th2-specific chemokines and inhibitors of $\alpha_{4} \beta_{1}$ integrins have been shown to induce profound anti-inflammatory effects. IBD, antiadhesion therapy has focused on two pathways: the $\alpha 2$ integrin/ICAM- 1 and the $\alpha 4$ integrin/MAd-CAM-1 interaction. It is important to point out that same clinical trials have been carried out using natalizumab (monoclonal antibodies to $\alpha 4$ integrin) and LDP-02 ( $\alpha 4, \beta 7$ integrin); and antisense to ICAM-1. Interestingly, 5-LOKO mice have not 
been used to elucidate whether 5-LO leukotrienes plays a role in the PMNs infiltration in rodent models of dinitrobenzene sulfonic acid (DNBS)induced colitis. This is surprising, as a substantial rise in leukotriene production it has been demonstrated in this experimental model of colitis ${ }^{29,30}$ as well as in patients with ulcerative colitis. ${ }^{31-33}$ In this study, we have investigated the role of 5 -LO in a Crohn's disease-like animal model, the DNBSinduced colitis in the mice.

\section{Materials and methods}

\section{Animals}

Mice (4-5 weeks old, 20-22g) with a targeted disruption of the 5-lipoxygenase gene (5-LOKO) and littermate wild-type controls (5-LOWT) were purchased from Jackson Laboratories (Harlan Nossan, Italy). The animals were housed in a controlled environment and provided with standard rodent chow and water. Animal care was in compliance with Italian regulations on protection of animals used for experimental and other scientific purposes (D.M. 116192) as well as with the EEC regulations (O.J. of E.C. L 358/1 12/18/1986).

\section{Experimental Groups}

Mice will be randomly allocated into the following groups: (i) 5-LOWT DNBS + saline group: 5-LOWT will be subjected to DNBS-induced colitis plus administration of saline $(N=10)$; (ii) 5 - $L O K O$ $D N B S+$ saline group: 5 -LOKO will be subjected to DNBS-induced colitis plus administration of saline $(N=10)$; (iii) 5 -LOWT + zileuton group: identical to the 5-LOWT DNBS + saline group but were administered zileuton $(50 \mathrm{mg} / \mathrm{kg}$ as emulsion in $0.5 \%$ hydroxyethyl cellulose in saline) which was given twice a day as an oral gavage (o.s.) starting $24 \mathrm{~h}$ before the induction of colitis until they were killed; (iv) 5-LOWT Sham + saline: 5-LOWT mice were subjected to the experimental procedures as the above groups except instead of DNBS $100 \mu \mathrm{l}$ of $50 \%$ ethanol were administered to the mice $(N=10)$; $(\mathrm{v})$ 5-LOKO Sham + saline: 5-LOKO mice were subjected to the surgical procedures as the above groups except that instead of DNBS $100 \mu \mathrm{l}$ of $50 \%$ ethanol were administered to the mice $(N=10)$; and (vi) 5-LOWT Sham + zileuton group: identical to 5-LOWT Sham + saline group except for the administration of zileuton. The dosage of zileuton regimen has been previously shown to reduced colon injury in a rat model of experimental colitis. ${ }^{34}$

\section{Induction of Experimental Colitis}

Colitis was induced with a very low dose of DNBS (4 mg per mouse) by using a modification ${ }^{35}$ of the method first described in rats. ${ }^{36}$ In preliminary experiments, this dose of DNBS was found to induce reproducible colitis without mortality. Mice were anesthetized by Enflurane. DNBS (4 mg in $100 \mu \mathrm{l}$ of $50 \%$ ethanol) was injected into the rectum through a catheter inserted $4.5 \mathrm{~cm}$ proximally to the anus. Vehicle alone ( $100 \mu \mathrm{l}$ of $50 \%$ ethanol) was administered in control experiments (sham). Thereafter, the animals were kept for $15 \mathrm{~min}$ in a Trendelenburg position to avoid reflux. After colitis and shamcolitis induction, the animals were observed for 4 days. On day 4, the animals were weighed and anesthetized with chloral hydrate, and the abdomen was opened by a midline incision. The colon was removed, freed from surrounding tissues, opened along the antimesenteric border, rinsed, weighed, and processed for histology and immunohistochemistry. Colon damage (macroscopic damage score) was evaluated and scored by two independent observers as described previously ${ }^{34,37,38}$ according to the following criteria: 0 , no damage; 1 , localized hyperemia without ulcers; 2 , linear ulcers with no significant inflammation; 3, linear ulcers with inflammation at one site; 4 , two or more major sites of inflammation and ulceration extending $>1 \mathrm{~cm}$ along the length of the colon; and $5-8$, one point is added for each centimeter of ulceration beyond an initial $2 \mathrm{~cm}$.

\section{Light Microscopy}

After fixation for 1 week at room temperature in Dietrich solution (14.25\% ethanol, $1.85 \%$ formaldehyde, $1 \%$ acetic acid), samples were dehydrated in graded ethanol and embedded in Paraplast (Sherwood Medical, Mahwah, NJ, USA). Thereafter, 7- $\mu \mathrm{m}$ sections were deparaffinized with xylene, stained with hematoxylin-eosin and trichromic van Giesson's stain, and observed in a Dialux 22 Leitz (Wetziar, Germany) microscope. In order to have a quantitative estimation of colon damage, section ( $N=6$ for each animals) was scored by two independent observers blinded to the experimental protocol. The following morphological criteria were considered: score 0, no damage; score 1 (mild), focal epithelial oedema and necrosis; score 2 (moderate), diffuse swelling and necrosis of the villi; score 3 (severe), necrosis with presence of neutrophil infiltrate in the submucosa; score 4 (highly severe), widespread necrosis with massive neutrophil infiltrate and hemorrhage.

\section{Myeloperoxidase Activity}

Myeloperoxidase (MPO) activity, an indicator of PMN accumulation, was determined as previously described. ${ }^{39}$ At 4 days after intracolonic injection of DNBS, the colon was removed and weighed. The colon was homogenized in a solution containing $0.5 \%$ hexa-decyl-trimethyl-ammonium bromide dissolved in $10 \mathrm{mM}$ potassium phosphate buffer ( $\mathrm{pH} 7)$ 
and centrifuged for $30 \mathrm{~min}$ at $20000 \mathrm{~g}$ at $4^{\circ} \mathrm{C}$. An aliquot of the supernatant was then allowed to react with a solution of tetra-methyl-benzidine $(1.6 \mathrm{mM})$ and $0.1 \mathrm{mM} \mathrm{H}_{2} \mathrm{O}_{2}$. The rate of change in absorbance was measured spectrophotometrically at $650 \mathrm{~nm}$. MPO activity was defined as the quantity of enzyme degrading $1 \mu \mathrm{mol}$ of peroxide per minute at $37^{\circ} \mathrm{C}$ and was expressed in units per gram weight of wet tissue.

\section{Intestinal Permeability}

On the fourth day of the experiment, mannitol $5 \mathrm{mg}$; lactulose dissolved in $0.5 \mathrm{ml}$ of normal saline were gavaged. Individual mice were then immediately placed in metabolic cages to allow for collection of urine for $4-5 \mathrm{~h}$ as previously described. ${ }^{40}$ Urinary sugar excretion was assessed by gas liquid chromatography.

\section{Localization of E-Selectin, P-Selectin, VCAM and ICAM-1 by Immunohistochemistry}

At 4 days after the administration of DNBS, the tissues were fixed in 10\% PBS-buffered formaldehyde and $8 \mu \mathrm{m}$ sections were prepared from paraffin-embedded tissues. The sections were permeabilized with $0.1 \%$ Triton X-100 in PBS for 20 min. Nonspecific adsorption was minimized by incubating the section in $2 \%$ normal goat serum in phosphate-buffered saline for $20 \mathrm{~min}$. Endogenous biotin or avidin binding sites were blocked by sequential incubation for $15 \mathrm{~min}$ with avidin and biotin. The sections were then incubated overnight with primary anti-E-selectin antibody (1:1000), antiVCAM-1 antibody (1:500), anti-P-selectin antibody (1:500), anti-ICAM-1 antibody (1:500), or with control solutions. To verify the binding specificity for E-selectin, P-selectin, VCAM-1, and ICAM-1, some sections were also incubated with primary antibody only (no secondary antibody) or with secondary antibody only (no primary antibody). In these situations, no positive staining was found in the sections indicating that the immunoreactions were positive in all the experiments carried out. Immunocytochemistry photographs $(N=5)$ were assessed by densitometry by using the Optilab Graftek software on a Macintosh personal computer.

\section{In Vitro Chemotactic Assay}

Peripheral blood was collected by cardiac puncture from either 5-LOWT or 5-LOKO mice. PMN counts were determined manually on slides of Wright's stain prepared with Cytospin. There were no statistically significant differences in the number of peripheral lymphocytes, monocytes, atypical lymphocytes, or eosinophils between the 5-LOWT or 5-LOKO mice. In order to confirm the role of 5-LO on chemotaxis, some purified 5-LOWT PMNs were also incubated for $15 \mathrm{~min}$ in the absence or presence of zileuton $(50 \mu \mathrm{g} / \mathrm{ml})$. The dose of zileuton was chosen in agreement with a previous study. ${ }^{41}$ PMN chemotaxis was quantified using a Transwell system (polycarbonate filters with pore size $5 \mu \mathrm{m}$ ) as described by La et $a .^{42}$ Cells were placed in the top well in a total volume of $100 \mu \mathrm{l}$, and IL-8 (30 ng/ ml) as previously described ${ }^{43}$ or medium (RPMI 1640 with $0.5 \%$ FBS) was added to the lower chamber. Plates were incubated for $2 \mathrm{~h}$ in a humidified incubator at $37^{\circ} \mathrm{C}$ with $5 \% \quad \mathrm{CO}_{2}$. Cells remaining on top of the filter were absorbed off and the filter tops were carefully washed to ensure removal of nonmigrated cells. The plates were centrifuged (1200 r.p.m., $5 \mathrm{~min}$ at room temperature) to pellet cells on the underside of the filters. The filter was removed and cells in the bottom wells were stained in Turk's solution $(0.01 \%$ crystal violet in $3 \%$ acetic acid) and counted by light microscopy.

\section{Reagents}

Zileuton was purchased from Sequioa Research Products (Oxford, UK). Biotin blocking kit, biotinconjugated goat anti-rabbit IgG and avidin-biotin peroxidase complex were obtained from Vector Laboratories (Burlingame, CA, USA). Primary antibodies for immunohistochemistry were purchased by Pharmingen. Reagents and secondary and nonspecific IgG antibody for immunohistochemical analysis were from Vector Laboratories Inc. All other reagents and compounds used were obtained from Sigma Chemical Company.

\section{Statistical Analysis}

All values in the figures and text are expressed as mean \pm s.e.m. of $N$ observations, where $N$ represents the number of animals studied. In the experiments involving histology or immunohistochemistry, the figures shown are representative of at least three experiments performed on different experimental days. Data sets were examined by one- and two-way analysis of variance and individual group means were then compared with Student's unpaired $t$-test. Nonparametric data were analyzed with the Fisher's exact test. A $P$-value less than 0.05 was considered significant.

\section{Results}

The Development of DNBS-Induced Colitis (Histology and General Assessment) is Reduced in 5-LOKO Mice and in 5-LOWT Mice Treated with Zileuton

At 4 days after intracolonic administration of DNBS, the colon appeared flaccid and filled with liquid stool. The macroscopic inspection of cecum, colon, and rectum showed presence of mucosal congestion, erosion, and hemorrhagic ulcerations (Figure 1a, d). 

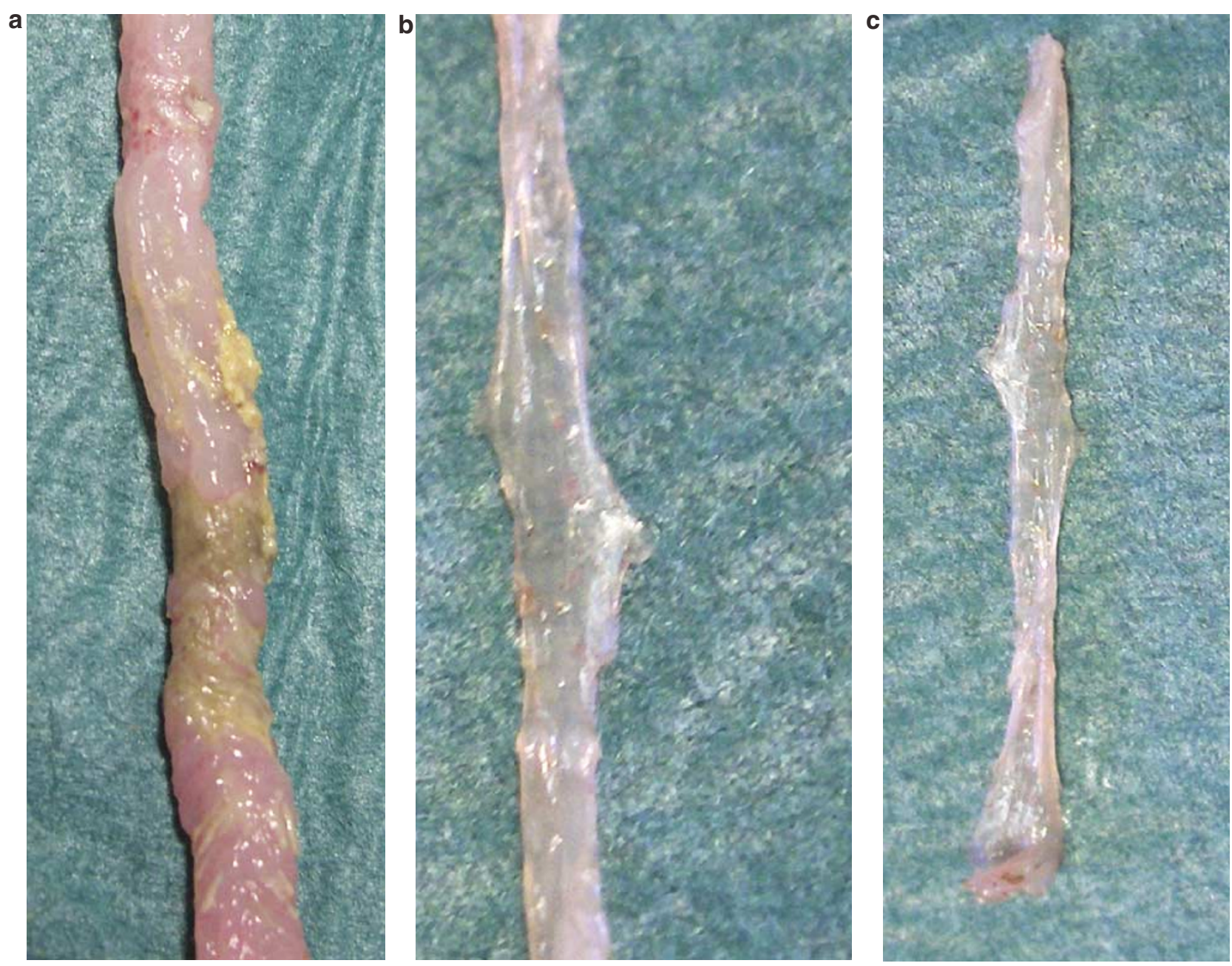

d

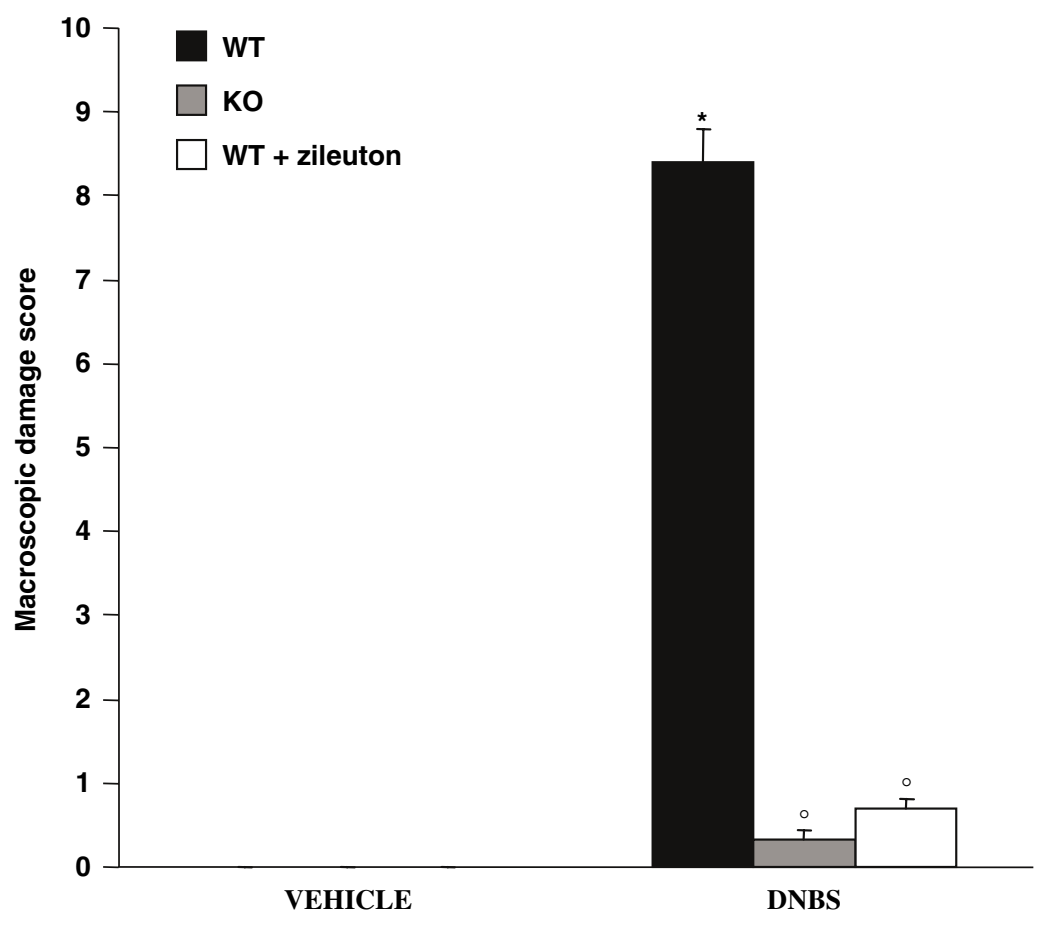



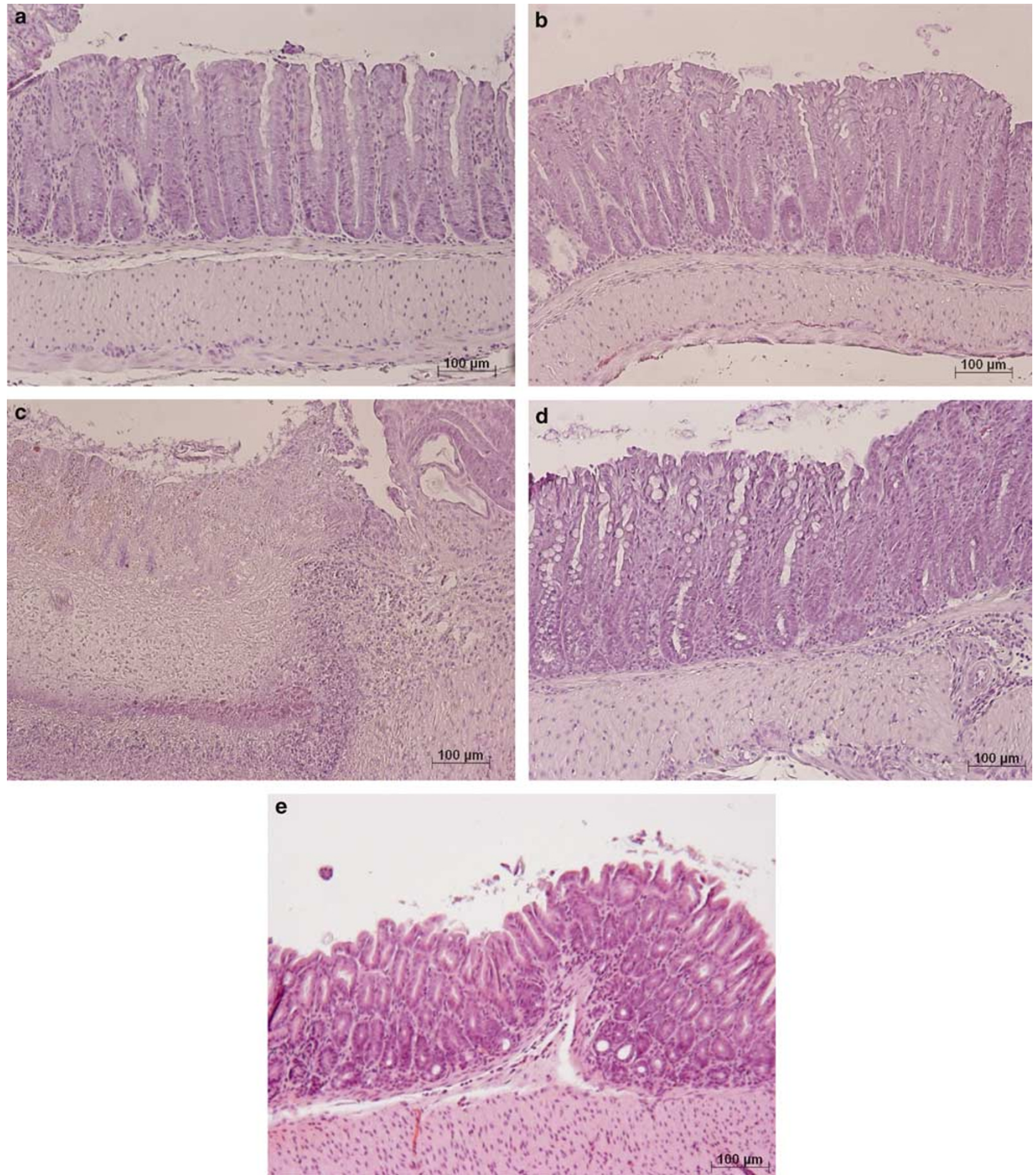

Figure 2 Effects of genetic 5-LO deletion on colon injury. No histological alteration was observed in the colon tissues collected either from sham-treated 5-LOWT (a) and from sham-treated 5-LOKO (b). Mucosal injury was produced after DNBS administration in 5-LOWT mice characterized by absence of epithelium and a massive mucosal and submucosal infiltration of inflammatory cells (c). The absence of 5-LO gene significantly reduced the extent and severity of the histological signs of colon injury (d). Similarly, the pharmacological inhibition of 5 -LO by administration with zileuton $(50 \mathrm{mg} / \mathrm{kg}$ per os twice a day) to DNBS 5-LOWT significantly reduced the histological signs of colon injury (e). This figure is representative of at least three experiments performed on different experimental days.

Figure 1 Effect of genetic 5-LO deletion on clinical expression of DNBS-induced colitis and macroscopic damage score. Colon tissues from DNBS-treated 5-LOWT mice at 4 days post-DNBS administration (a), the colon tissues collected from DNBS-treated 5-LOKO mice (b), and the colon tissues collected from DNBS-treated 5-LOWT mice treated with zileuton (50 mg/kg per os twice a day) (c). The macroscopic damage score (d) was made by two independent observers. This figure is representative of all the animals in each group. Data are means \pm s.e.m. of 10 mice for each group. ${ }^{*} P<0.01$ vs VEHICLE (sham); ${ }^{\circ} P<0.01$ vs DNBS 5-LOWT. 
The histopathological features included a transmural necrosis and edema and a diffuse leukocyte cellular infiltrate in the submucosa of colon section from DNBS-treated 5-LOWT mice (Figures 2c and 3). The observed inflammatory changes of the large intestine were associated with an increase in the weight of the colon with respect to vehicle-treated mice (sham) (Figure 4). The absence of 5-LO gene significantly reduced the extent and severity of the histological signs of colon injury (Figures 1b, d, 2d, and 3) as well as the colon weight which was similar to 5-LOKO vehicle-treated mice (sham) (Figure 4a). At 4 days after colitis induced by DNBS treatment, all 5-LOWT mice had diarrhea and a significant reduction in body weight (compared to the respective sham mice) expressed as the percent of the initial body weight lost (Figure 4b). Absence of a functional 5-LO gene in 5-LOKO mice resulted in a significant decrease of body weight loss (Figure 4b). Similarly, the treatment of 5-LOWT with zileuton, a potent 5-LO inhibitor, resulted in a significant decrease in the extent and severity of the injury of the large intestine (Figures 1c, d, 2e, 3, and 4). No histological alteration was observed in the colon tissue from vehicle-treated 5-LOWT and 5-LOKO mice (sham) (Figures 2a, b, and 3).

\section{Neutrophil Infiltration}

The above histological pattern of colon injury appeared to be correlated with the influx of leukocytes into the colon tissue. Therefore, we investigated the role of 5-LO on the neutrophils infiltration by measurement of the activity of myeloperoxidase in the colon. Myeloperoxidase activity was significantly elevated $(P<0.01)$ at

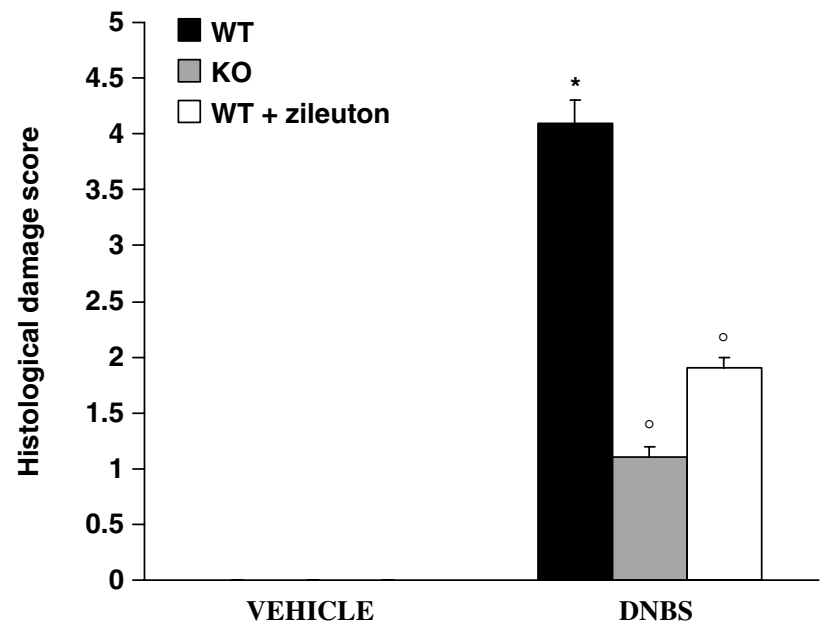

Figure 3 Effects of genetic or pharmacological 5-LO inhibition on histological damage score. The histological score were made by two independent observers. Data are means \pm s.e.m. of 10 mice for each group. ${ }^{*} P<0.01$ vs VEHICLE (sham); ${ }^{\circ} P<0.01$ vs DNBS 5-LOWT.
4 days after DNBS administration in 5-LOWT mice with respect to the correspondent vehicle-treated mice (sham) (Figure 5). In 5-LOKO mice colon, myeloperoxidase activity was significantly reduced $(P<0.01)$ in comparison to 5-LOWT animals (Figure $5)$ and almost similar to the correspondent sham mice. Similarly, the treatment of 5-LOWT with zileuton, resulted in a significant decrease in the neutrophils infiltration (Figure 5).

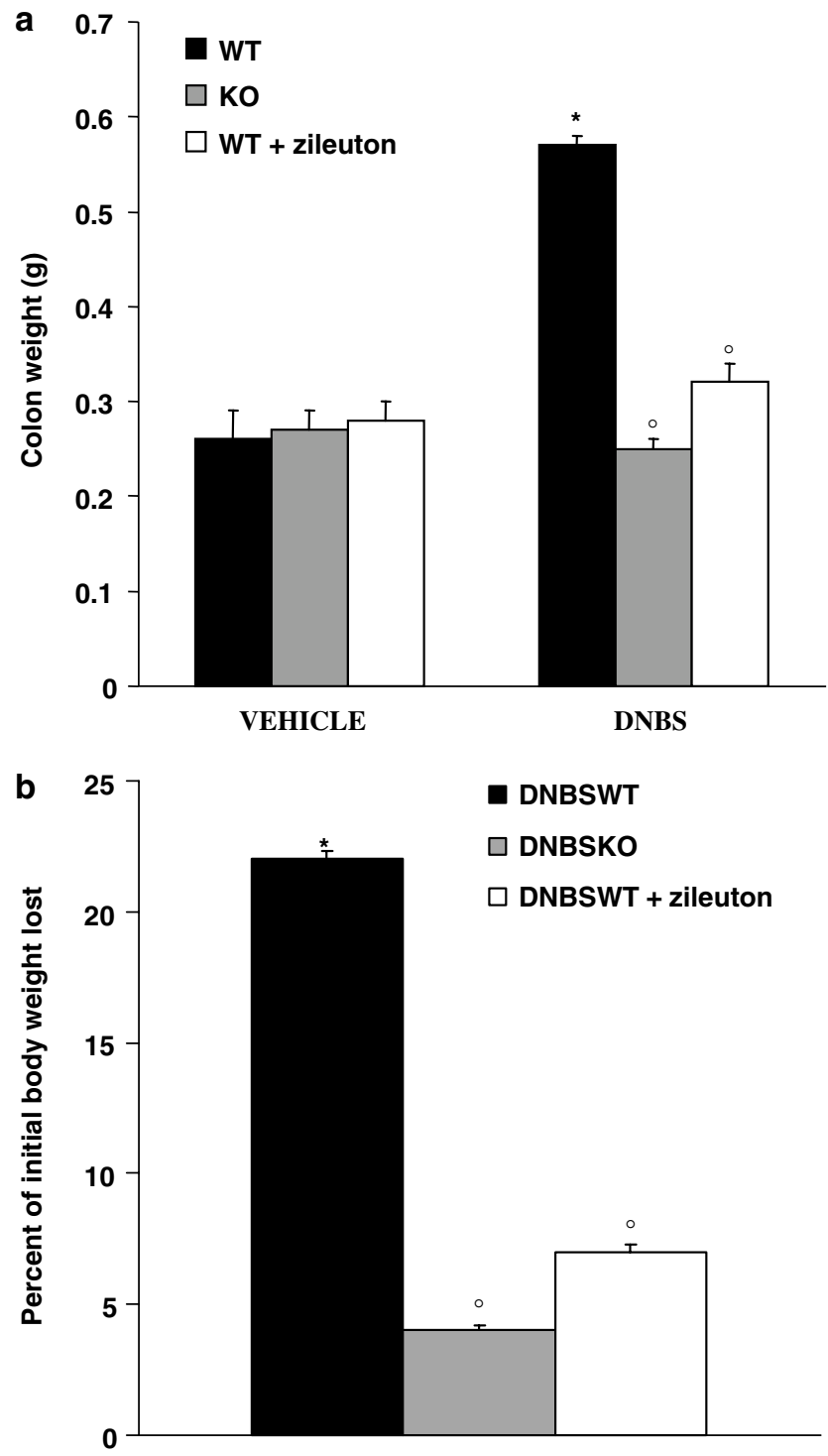

Figure 4 Effects of genetic or pharmacological 5-LO inhibition on colon weight (a) and body weight changes (b) after DNBS intracolonic administration. At 4 days after DNBS administration, a significant increase in the weight of the colon was observed (a) as well as a significant reduction in body weight increase (b). The absence of 5-LO gene or the treatment of DNBS 5-LOWT mice with zileuton ( $50 \mathrm{mg} / \mathrm{kg}$ per os twice a day) significantly reduced the extent and severity of the colon weight (a) as well as the less body weight increase (b). Data are means \pm s.e.m. of 10 mice for each group. ${ }^{*} P<0.01$ vs VEHICLE (sham); ${ }^{\circ} P<0.01$ vs DNBS 5-LOWT. 


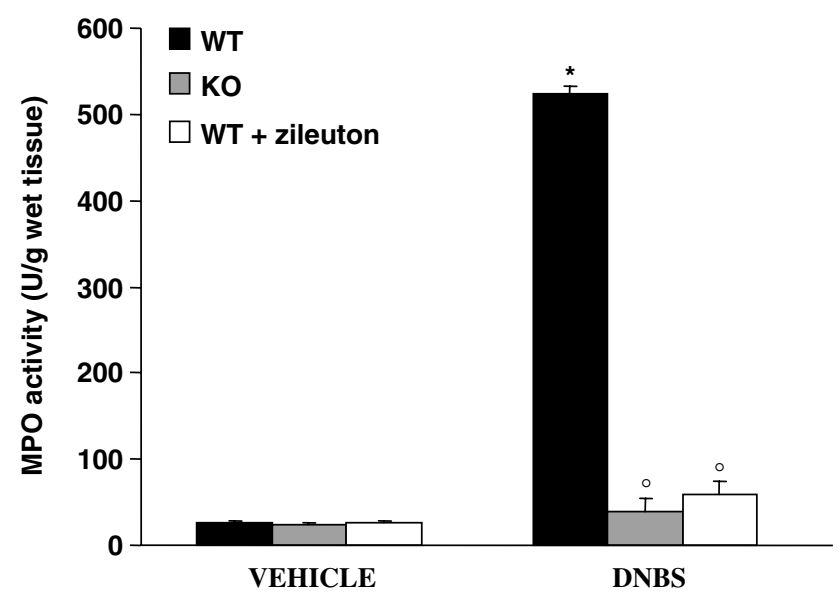

Figure 5 Effects of genetic or pharmacological 5-LO inhibition on colon neuthophil infiltration. Myeloperoxidase (MPO) activity was significantly increased in DNBS-treated 5-LOWT mice in comparison to vehicle-treated mice (sham). MPO activity was significantly reduced in DNBS-treated 5-LOKO mice as well as in DNBS-treated 5 -LOWT mice, which have received zileuton $(50 \mathrm{mg} / \mathrm{kg}$ per os twice a day). Data are means \pm s.e.m. of 10 mice for each group. ${ }^{*} P<0.01$ vs VEHICLE (sham); ${ }^{\circ} P<0.01$ vs DNBS 5-LOWT.

\section{Expression of Adhesion Molecules (ICAM-1,VCAM-1, P-Selectin and E-Selectin)}

Neutrophils infiltration in the colon tissues was associated with expression of adhesion molecules. In fact, at 4 days after DNBS administration, positive staining for ICAM-1 (Figure 6b and 7), for P-selectin (Figures 7 and 8b), for E-selectin (Figures 7 and 9b), and for VCAM-1 (Figures 7 and 10b) were found increased along the vessels from DNBS-treated 5LOWT mice. In DNBS-treated 5-LOKO mice, the staining for ICAM-1 (Figures 6c and 7), for P-selectin (Figures 7 and 8c), for E-selectin (Figures 7 and 9c), and for VCAM-1 (Figures 7 and 10c) was visibly and significantly reduced in comparison with the 5LOWT mice. Similarly, the treatment of 5-LOWT with zileuton, resulted in a significant decrease in the positive staining for ICAM-1 (Figures $6 \mathrm{~d}$ and 7), for P-selectin (Figures 7 and 8d), for E-selectin (Figures 7 and 9d), and for VCAM-1 (Figures 7 and 10d). It is important to underline that constitutive staining for ICAM-1 and no positive staining for P-selectin, E-selectin, and VCAM-1 was observed in
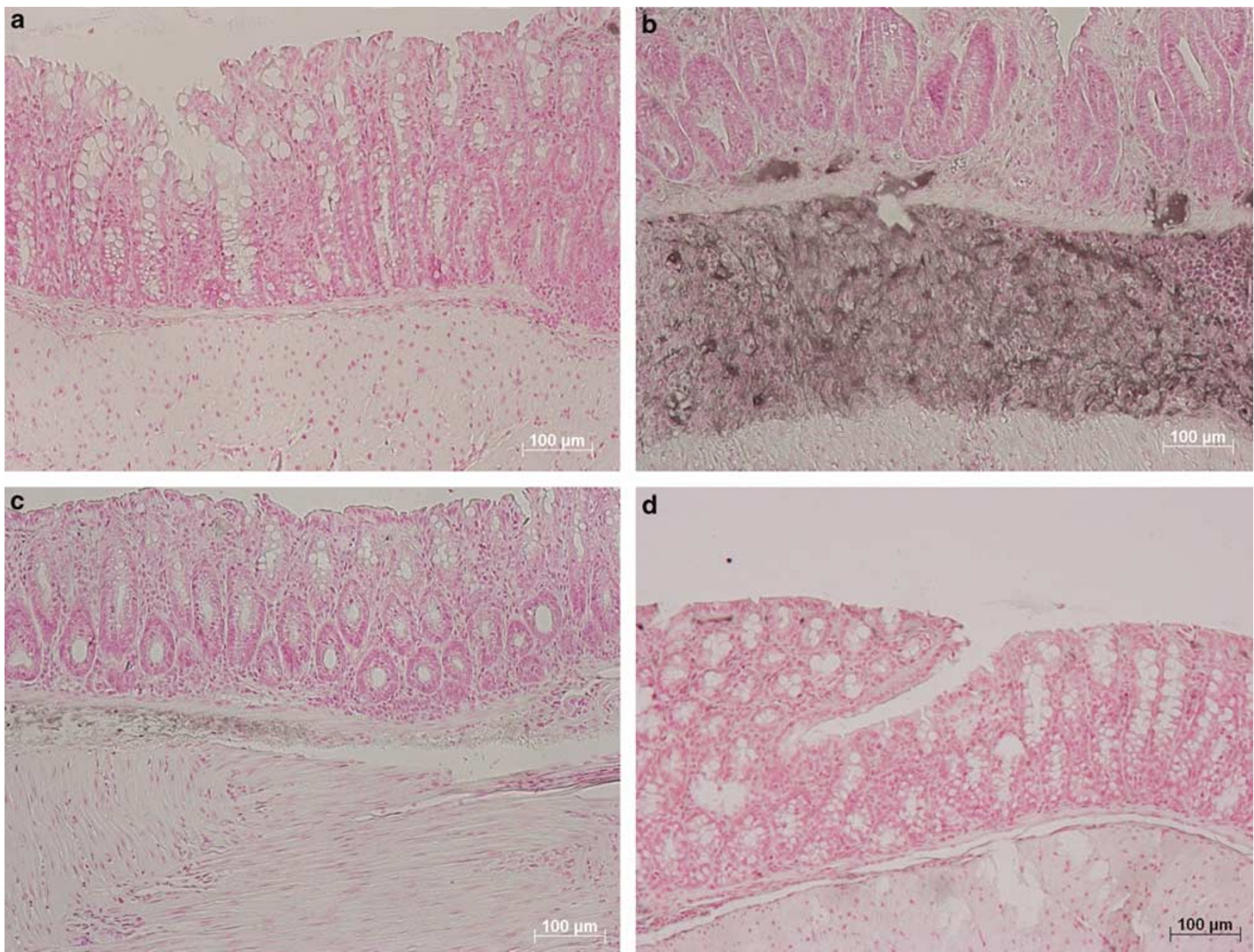

Figure 6 Immunohistochemical localization of ICAM-I in the colon. Constitutive staining for ICAM-1 was observed in colon tissues section from sham-treated mice (a). Section obtained from DNBS-treated 5-LOWT mice showed intense positive staining for ICAM-1 (b) on endothelial cells. The degree of endothelial staining for ICAM-1 was markedly reduced in tissue section obtained from DNBS-treated 5-LOKO mice (c) as well as in tissue section obtained from DNBS-treated 5-LOWT mice which have received zileuton (d). This figure is representative of at least three experiments performed on different experimental days. 


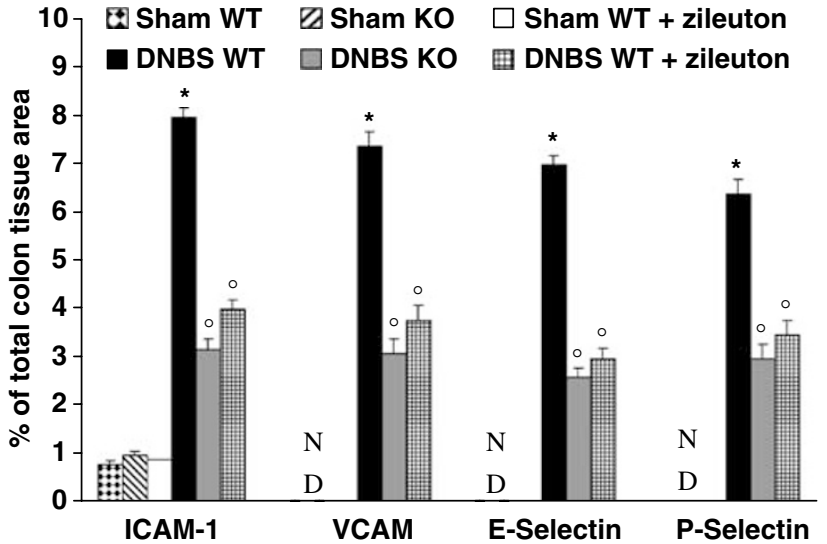

Figure 7 Typical densitometry evaluation. Densitometry analysis of immunocytochemistry photographs $(N=5)$ for ICAM-1, VCAM, P-selectin, and E-selectin from colon was performed. The assay was carried out by using the Optilab Graftek software on a Macintosh personal computer (CPU G3-266). Data are expressed as $\%$ of total tissue area. ND: not detectable. ${ }^{*} P<0.01$ vs SHAM $P<0.01$ vs DNBS 5-LOWT. lungs of vehicle-treated mice (sham) (Figures 6a, 7, 8a, 9a, and 10a).

\section{Intestinal Permeability}

For assessing baseline small bowel permeability, permeability probes (lactulose and mannitol) were administered by gavage, and urinary lactulose and mannitol excretion was measured in urine collected over a $4-5 \mathrm{~h}$ postgavage period and Lactulose/ mannitol (L/M) ratios were calculated. As indicated in Figure 11, the $\mathrm{L} / \mathrm{M}$ ratios was unchanged in the sham 5-LOWT and in sham 5-LOKO mice. On the contrary, in the urinary samples from DNBS-5LOWT mice, L/M ratios were significantly higher in comparison to the sham animals. The absence or inhibition of 5-LO in mice (animals with the 5-LOKO phenotype or 5-LOWT mice treated with zileuton) resulted in a pronounced reduction of the increase of L/M ratios (Figure 11).
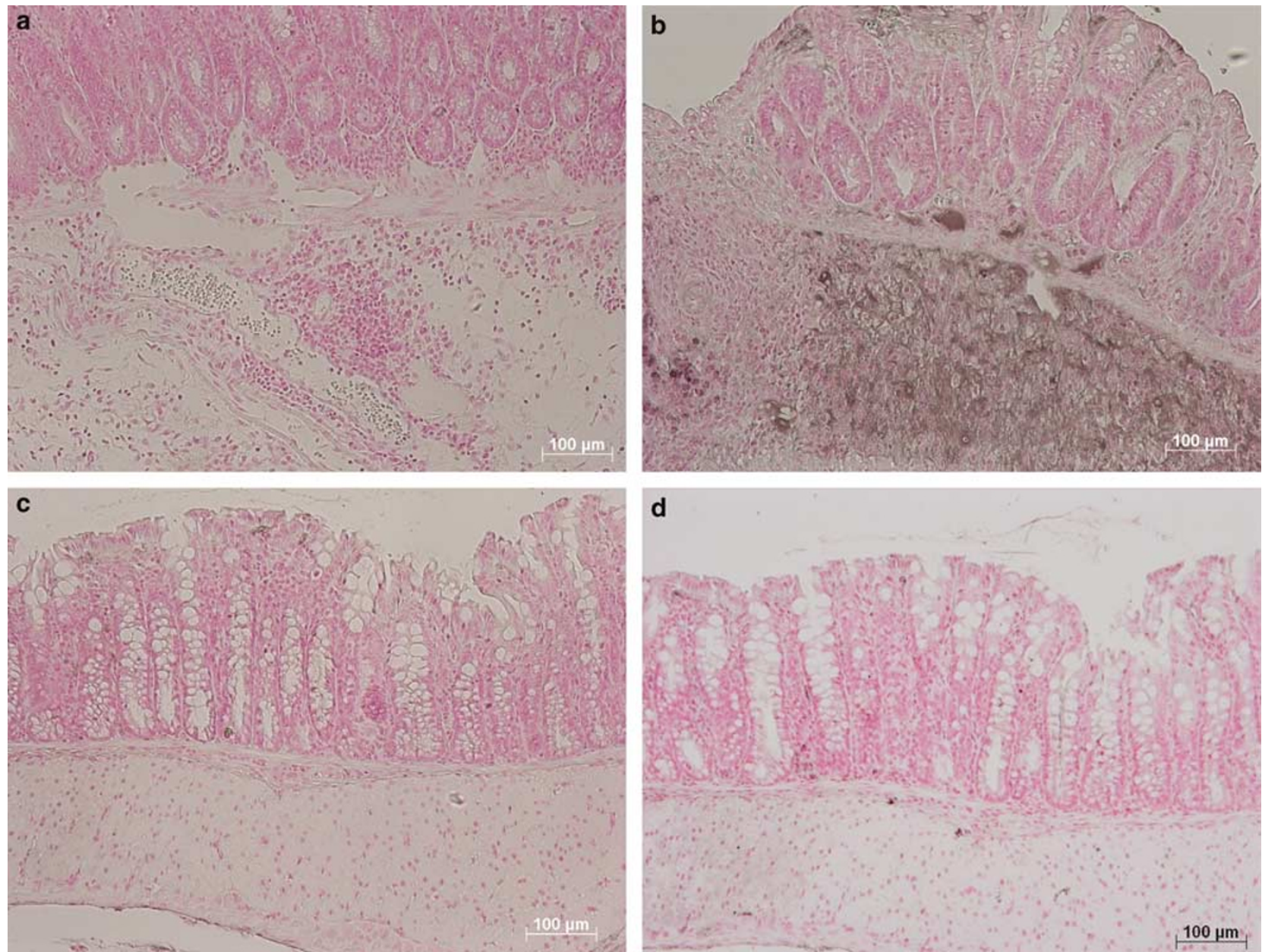

Figure 8 Immunohistochemical localization of P-selectin in the colon. No positive staining for P-selectin was observed in colon tissues section from sham-treated mice (a). Section obtained from DNBS-treated 5-LOWT mice showed intense positive staining for P-selectin (b) on endothelial cells. The degree of endothelial staining for P-selectin was markedly reduced in tissue section obtained from DNBStreated 5-LOKO mice (c) as well as in tissue section obtained from DNBS-treated 5-LOWT mice, which have received zileuton (d). This figure is representative of at least three experiments performed on different experimental days. 

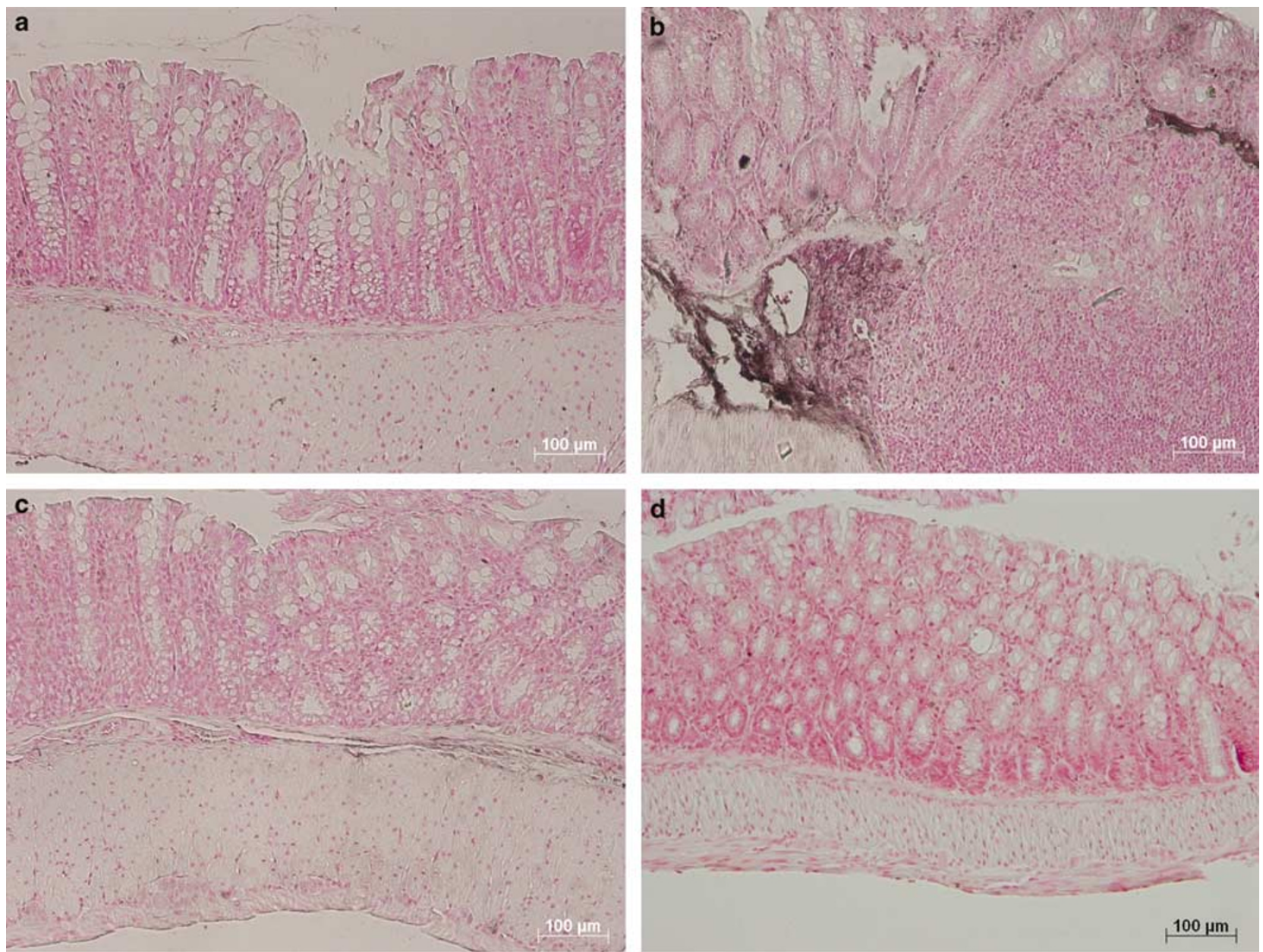

Figure 9 Immunohistochemical localization of E-selectin in the colon. No positive staining for E-selectin was observed in colon tissues section from sham-treated mice (a). Section obtained from DNBS-treated 5-LOWT mice showed intense positive staining for E-selectin (b) on endothelial cells. The degree of endothelial staining for E-selectin was markedly reduced in tissue section obtained from DNBStreated 5-LOKO mice (c) as well as in tissue section obtained from DNBS-treated 5-LOWT mice, which have received zileuton (d). This figure is representative of at least three experiments performed on different experimental days.

\section{In Vitro PMN Chemotaxis}

Leukotrienes and in particularly leukotriene (LT) $\mathrm{B}_{4}$ play an important role in the adhesion of leukocytes to endothelium, chemotaxis, and PMN degranulation. $^{9,44}$ We therefore assessed the in vitro chemotactic response of peripheral blood leukocytes from 5-LOWT and 5-LOKO mice stimulated with IL-8 $(30 \mathrm{ng} / \mathrm{ml})$, which produced optimal PMN chemotaxis $^{43}$ in a Transwell chemotactic assay. Basal motility of PMN (with medium in both upper and lower wells) was not significantly different for 5-LOWT and 5-LOKO cells (Figure 12). When we tested the chemotactic response to IL-8 (IL-8 in the lower well), significantly more 5-LOWT PMN reached the lower well than 5-LOKO cells, indicating that the chemotactic response to IL-8 is significantly reduced in 5-LOKO cells (Figure 12). Similar results were obtained when we analyzed the chemotactic response of 5-LOWT cell incubated for $15 \mathrm{~min}$ with zileuton $(50 \mu \mathrm{g} / \mathrm{ml})$ (Figure 12).

\section{Discussion}

We demonstrate here that the absence of the 5-LO gene significantly reduced: (i) the degree of diarrhea and weight loss, (ii) the degree of colonic injury, and (iii) the inflammatory cells infiltration caused by DNBS in the colon. Furthermore, using mice in which the gene for 5-LO was deleted (5-LO knockout mice; 5-LOKO), we demonstrate here that the activation of 5-LO mediates leukocyte-endothelial interactions by regulating the expression of $\mathrm{P}$ selectin, E-selectin, ICAM-1, and VCAM-1 during experimental colitis. In 5-LOKO mice subjected to DNBS-induced colitis, the upregulation of P-selectin, E-selectin, ICAM-1, and VCAM-1 in the lung was largely attenuated. Similarly, the treatment with zileuton, a potent 5-LO inhibitor, significantly reduced all the inflammatory parameters. All of these findings support the view that inhibition of 5LO pathway exerts potent anti-inflammatory effects. What, then, is the mechanism by which inhibition of 5-LO inhibit the colon inflammation caused by 

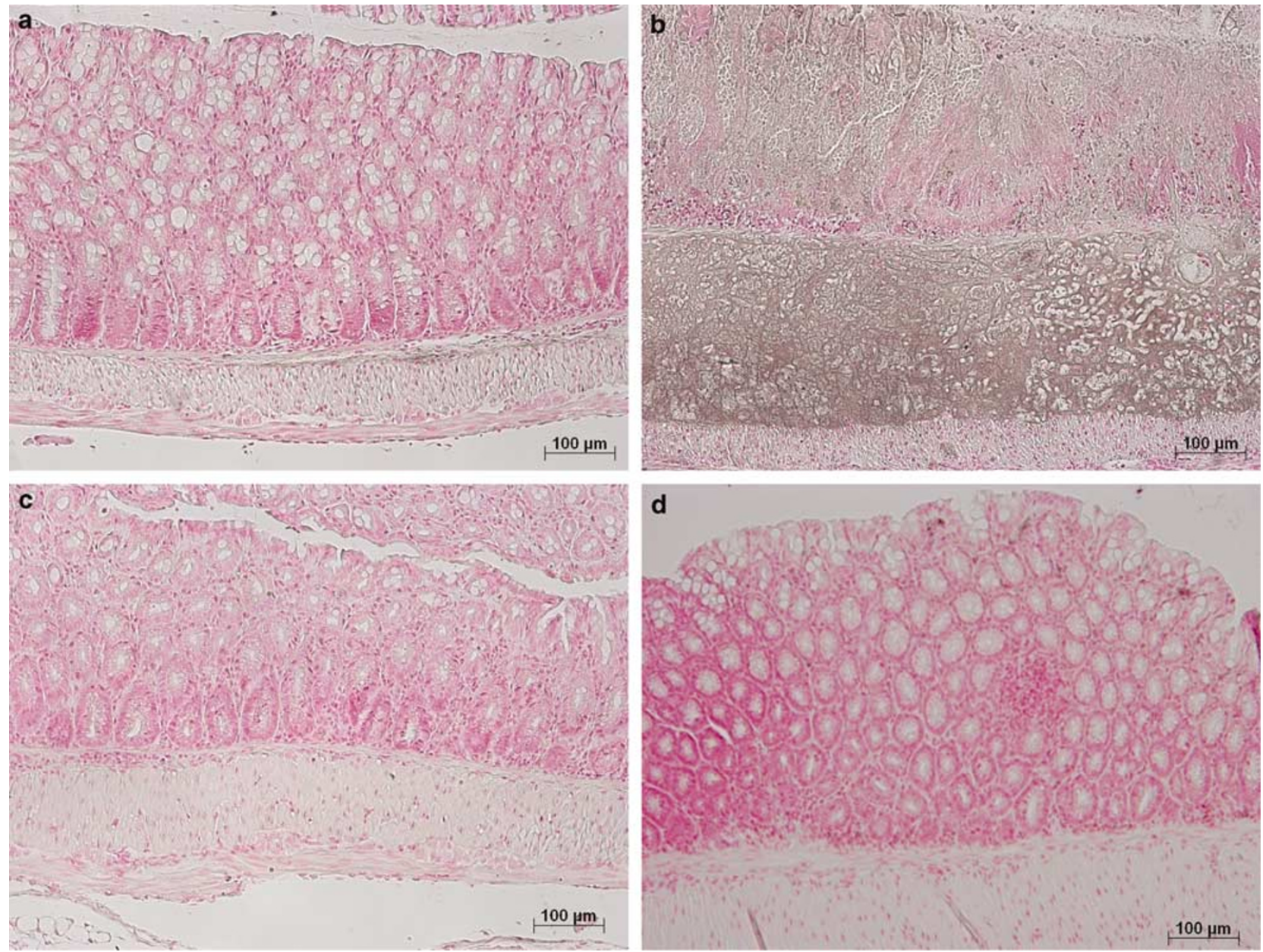

Figure 10 Immunohistochemical localization of VCAM-1 in the colon. No positive staining for VCAM was observed in colon tissues section from sham-treated mice (a). Section obtained from DNBS-treated 5-LOWT mice showed intense positive staining for VCAM (b) on endothelial cells. The degree of endothelial staining for VCAM was markedly reduced in tissue section obtained from DNBS-treated 5LOKO mice (c) as well as in tissue section obtained from DNBS-treated 5-LOWT mice, which have received zileuton (d). This figure is representative of at least three experiments performed on different experimental days.

injection of DNBS? Endothelial cells appear to be major regulators of the neutrophil traffic, regulating the process of neutrophil chemoattraction, adhesion and emigration from the vasculature to the tissue. P-selectin is rapidly recruited to the cell surface of either platelets or endothelial cells from preformed storage pools after exposure to, for example, hydrogen peroxide, thrombin, histamine, or complement, and allows the leukocytes to roll along the endothelium. ${ }^{45-47}$ E-selectin is expressed in skin microvessels under baseline conditions, ${ }^{22}$ and there is some evidence that E-selectin is of particular importance in skin inflammation, because it supports the recruitment of skin-specific $\mathrm{T}$ lymphocytes, ${ }^{23}$ ICAM-1 is constitutively expressed on the surface of endothelial cells and is involved in the neutrophil adhesion. ${ }^{48}$ Hypoxic or injured endothelial cells synthesise pro-inflammatory cytokines, which can upregulate endothelial expression of the constitutive adhesion molecule ICAM-1 in an autocrine fashion. ${ }^{49,50}$ Significant expression of ICAM-1 in microvessels of ischemic tissues occurs within $1 \mathrm{~h}$ after reperfusion. ${ }^{51,52}$ VCAM-1 is expressed on both large and small vessels only after the endothelial cells are stimulated by cytokines. Recently, it has been demonstrated that certain melanoma cells can use VCAM-1 to adhere to the endothelium, and VCAM-1 may participate in monocyte recruitment to atherosclerotic sites. The upregulation expression of P-selectin, E-selectin, ICAM-1, and VCAM-1 corresponds with the induction of neutrophil recruitment, which is maximal within the first hour of reperfusion, and persists, at lower rate, in the late phase of reperfusion. ${ }^{53,54}$ In accordance with these findings, we observed that DNBS (after 4 days) induced the appearance of P-selectin, E-selectin, and VCAM-1 on the endothelial vascular wall and upregulated the surface expression of ICAM-1 on endothelial cells in the lung section from 5-LOWT mice. The deletion of the gene encoding for 5 - $\mathrm{LO}$ as well as the pharmacolocial inhibition of 5 -LO (zileuton treatment) abolished the upregulation of 


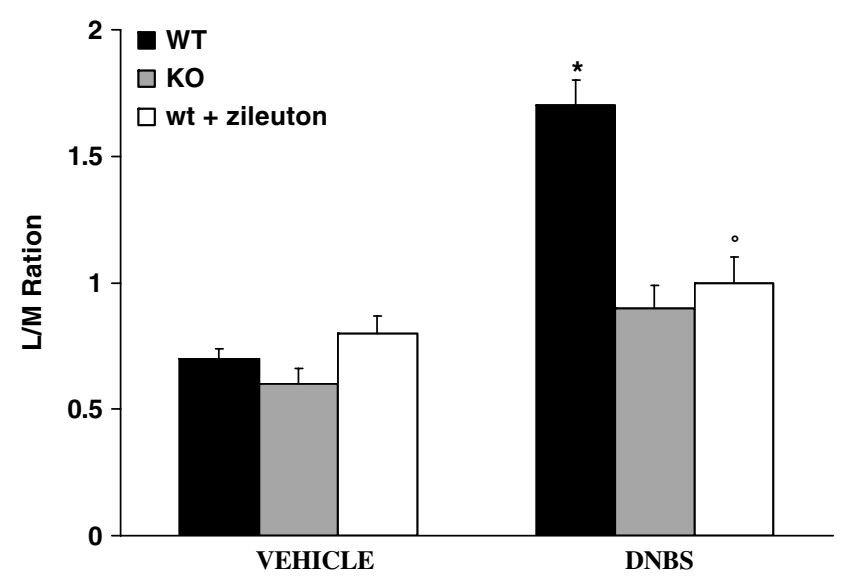

Figure 11 Effects of 5-LO inhibition on intestinal permeability. For assessing baseline small bowel permeability, permeability probes (lactulose and mannitol) were administered by gavage, and urinary lactulose and mannitol excretion was measured in urine collected over a $4-5 \mathrm{~h}$ postgavage period and $\mathrm{L} / \mathrm{M}$ ratios were calculated. The L/M ratios was unchanged in the sham 5-LOWT and in sham 5-LOKO mice. On the contrary in the urinary samples from DNBS 5-LOWT mice L/M ratios were significantly higher in comparison to the sham animals. The absence or inhibition of 5-LO in mice (animals with the 5-LOKO phenotype or 5-LOWT mice treated with zileuton) resulted in a pronounced reduction of the increase of $\mathrm{L} / \mathrm{M}$ ratios. Data are means + s.e.m. of 10 mice for each group. ${ }^{*} P<0.01$ vs VEHICLE (sham); ${ }^{\circ} \mathrm{P}<0.01$ vs DNBS 5-LOWT.

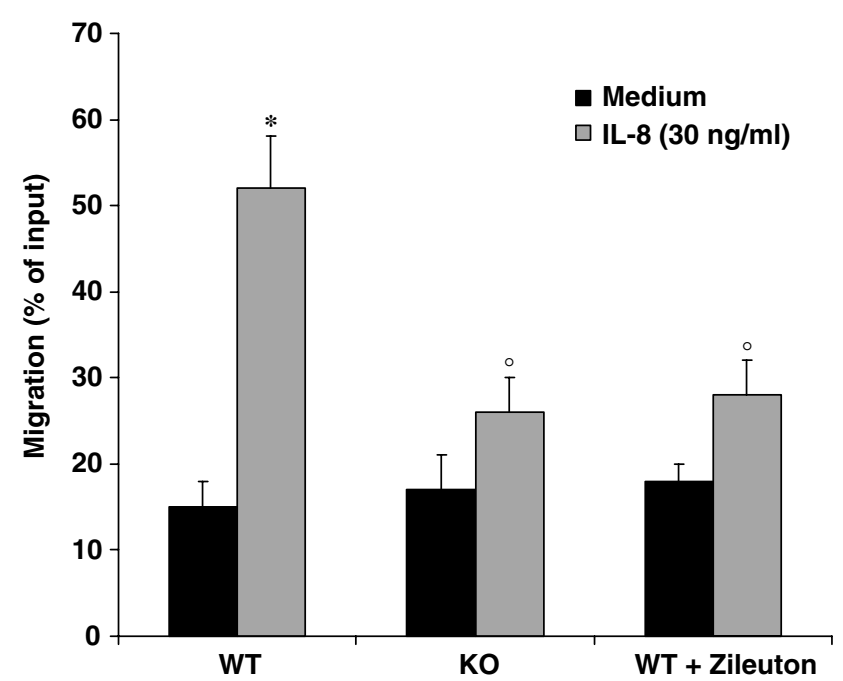

Figure 12 Chemotactic response of 5-LOWT and 5-LOKO PMN. Blood PMN chemotaxis was determined in a Transwell assay. Medium alone or IL-8 $(30 \mathrm{ng} / \mathrm{ml})$ was added to the lower well and cells were placed in the upper well in medium for $2 \mathrm{~h}$. In order to confirm the role of 5-LO on chemotaxis, some purified 5-LOWT PMNs were also incubated for $15 \mathrm{~min}$ in the absence or presence of zileuton ( $50 \mu \mathrm{g} / \mathrm{ml}$ ). Data represent percentage of cells from the total number used that reached the lower well, $n=6$ /group. ${ }^{*} P<0.01$ vs medium-incubated cells, ${ }^{\circ} P<0.01$ vs 5 -LOWT PMNs incubated with IL-8.

P-selectin, E-selectin, ICAM-1, and VCAM-1, but did not affect the constitutive expression of ICAM-1 on endothelial cells. These results suggest that inhibi- tion of 5-LO activity may interfere with the interaction of neutrophils and endothelial cells both at the early rolling phase mediated by P-selectin and E-selectin and at the late firm adhesion phase mediated by ICAM-1 and VCAM-1. The absence of an increased expression of the adhesion molecules in the colon tissue of DNBS-treated 5-LOKO mice correlated with the reduction of leukocyte infiltration, as assessed by the specific granulocyte enzyme myeloperoxidase, and with the decrease of tissue damage as evaluated by histological examination. It is noteworthy, however that tissue myeloperoxidase activity was not completely abolished, but was almost similar to the correspondent sham mice. This result is consistent with previous studies demonstrating that constitutive levels of ICAM-1 appear to be sufficient to support a lower degree of CD11/CD18-dependent trans-endothelial migration of activated neutrophils. . $^{5,56}$

The inflammatory response for example after topical application of AA depends on the formation of the unstable intermediate $\mathrm{LTA}_{4}$ by the enzyme 5-lipoxygenase. $\mathrm{LTA}_{4}$ is further metabolized into either $\mathrm{LTB}_{4}$ or cysteinyl LTs including $\mathrm{LTC}_{4}$ and $\mathrm{LTD}_{4} . \mathrm{LTB}_{4}$ is a potent chemoattractant for PMN and the cysteinyl LTs increase vascular permeability. 5-Lipoxygenase-deficient animals cannot produce $\mathrm{LTB}_{4}$ and $\mathrm{LTC}_{4}$ and therefore have reduced inflammatory responses to topical application of AA. ${ }^{57,58}$ The reduced influx of PMN observed in vivo may well be the result of reduced production of $\mathrm{LTB}_{4}$ in 5 -LOKO cells or 5-LOWT cells treated with zileuton, as was observed in chemotaxis experiments in vitro. Although zileuton, a well-known 5-LO inhibitor, has not proved to be effective in the treatment of ulcerative colitis in clinical trial, ${ }^{59}$ it has been shown to reduce the severity of experimental colitis in rats in a similar colitis model. ${ }^{60,61}$ Recently, Holma et $a l^{61}$ have demonstrated that zileuton failed to decrease the inflammatory reaction in TNBSinduced colitis in spite of the fact that it reduced LTB4 production at $72 \mathrm{~h} .{ }^{62}$ Taken together with the other studies this implies, as suggested by Holma, that leukotrienes might be more important during the later phase of the TNBS models. In agreement with these studies, we have observed that the genetic absence of 5-LO in 5-LOKO mice as well as the treatment of 5-LOWT mice with zileuton exert a protective effect at 4 days after DNBS administration.

Furthermore, intestinal permeability reflects the integrity of the intestinal mucosal barrier, which restricts the passive permeation of luminal substances. ${ }^{63}$ It is well known that altered intestinal permeability has been reported in various intestinal conditions associated with diarrhea such as celiac disease, ${ }^{64}$ IBD, ${ }^{65}$ infectious gastroenteritis, ${ }^{66-68}$ and food intolerance or allergy. ${ }^{69,70}$ It is possible to assess intestinal permeability in vivo by measuring the urinary excretion of hydrosoluble and not degradable probes given orally. The $\mathrm{L} / \mathrm{M}$ test uses a mixture 
of two nonmetabolized sugars, minimizing the influence of variables such as gastric emptying, intestinal motility, and renal function, which affect both markers equally. Moreover, it is a nontoxic, noninvasive test and the laboratory procedure is simple and inexpensive. ${ }^{71}$ The $\mathrm{L} / \mathrm{M}$ test is used in the diagnosis and follow-up of $\operatorname{celiac}^{72-74}$ and Crohn's disease..$^{75,76}$

As clearly demonstrated in this study, the absence or inhibition of 5-LO in mice (animals with the 5-LOKO phenotype or 5-LOWT mice treated with zileuton) resulted in a pronounced reduction of the increase of L/M ratios observed at 4 days after DNBS administration in 5-LOWT mice. It is also important to point out that the genetic as well as the pharmacological inhibition of 5-LO did not change the physiological $\mathrm{L} / \mathrm{M}$ ratios in the sham-treated mice.

In conclusion, the data presented here demonstrate that 5-LO is involved in the regulation of the expression of adhesion molecules and that, consequently, 5-LO plays a role in the tissue infiltration of neutrophils. Taken together, the data presented in the present study and in another recent report ${ }^{58}$ demonstrate that 5 -LO regulates the infiltration of neutrophils into the inflamed tissues via a number of distinct mechanisms. Based on the results of the present study and on the important role of neutrophils infiltration in patients with IBD, further investigations, using LT receptor antagonists or more potent and selective inhibitors of 5-LO, will be performed in order to clarify the exact mechanism responsible for the observed anti-inflammatory events.

\section{References}

1 Cuzzocrea S. Emerging biotherapies for inflammatory bowel disease. Expert Opin Emerg Drugs 2003;8: 339-347.

2 Elson CO. Experimental models of intestinal inflammation: new insights into mechanisms of mucosal homeostasis. In: Ogro PL, Lamm ME, Bienenstock J, Mestecky J, Strober W, McGhee JR (eds). Mucosal Immunology. Academic Press: San Diego, 1999, pp 1007-1024.

3 Snapper SB, Rosen FS, Mizoguchi E, et al. WiskottAldrich syndrome protein-deficient mice reveal a role for WASP in $\mathrm{T}$ but not $\mathrm{B}$ cell activation. Immunity 1998;9:81-91.

4 Matsumoto S, Okabe Y, Setoyama H, et al. Inflammatory bowel disease-like enteritis caecitis in a senescence accelerated mouse P1/Yit strain. Gut 1998; 43:71-78.

5 Blumberg RS, Saubermann LJ, Strober W. Animal models of mucosal inflammation and their relation to human inflammatory bowel disease. Curr Opin Immunol 1999;11:648-656.

6 Cuzzocrea S, McDonald MC, Mazzon E, et al. The tyrosine kinase inhibitor tyrphostin AG 126 reduced the development of colitis in the rat. Lab Invest 2000;80:1439-1453.
7 Mazzon E, Puzzolo D, Caputi AP, et al. Role of IL-10 in hepatocyte tight junction alteration in mouse model of experimental colitis. Mol Med 2002;8: 353-366.

8 Henderson Jr WR. The role of leukotrienes in inflammation. Ann Intern Med 1994;121:684-697.

9 Dahlen SE, Bjork J, Hedqvist P, et al. Leukotrienes promote plasma leakage and leukocyte adhesion in postcapillary venules: in vivo effects with relevance to the acute inflammatory response. Proc Natl Acad Sci USA 1981;78:3887-3891.

10 Dahlen SE, Hedqvist $\mathrm{P}$, Hammarstrom S, et al. Leukotrienes are potent constrictors of human bronchi. Nature 1980;288:484-486.

11 Drazen JM, Austen KF. Leukotrienes and airway responses. Am Rev Respir Dis 1987;136:985-998.

12 Lewis RA, Austen KF, Soberman RJ. Leukotrienes and other products of the 5-lipoxygenase pathway. Biochemistry and relation to pathobiology in human diseases. N Engl J Med 1990;323:645-655.

13 McIntyre TM, Zimmerman GA, Prescott SM. Leukotrienes C4 and D4 stimulate human endothelial cells to synthesize platelet-activating factor and bind neutrophils. Proc Natl Acad Sci USA 1986;83:2204-2208.

14 Patel KD, Zimmerman GA, Prescott SM, et al. Oxygen radicals induce human endothelial cells to express GMP-140 and bind neutrophils. J Cell Biol 1991; 112:749-759.

15 Ratych RE, Chuknyska RS, Burkley GB. The primary localisation of free radical generation after anoxia/ reoxygenation in isolated endothelial cells. Surgery 1987;102:122-131.

16 Bevilacqua MP, Stengelin S, Gimbrone Jr MA, et al. Endothelial leukocyte adhesion molecule 1: an inducible receptor for neutrophils related to complement regulatory proteins and lectins. Science 1989;243: 1160-1165.

17 Hickey MJ, Kanwar S, McCafferty DM, et al. Varying roles of E-selectin and P-selectin in different microvascular beds in response to antigen. J Immunol 1999;162:1137-1143.

18 Bullard DC, Kunkel EJ, Kubo H, et al. Infectious susceptibility and severe deficiency of leukocyte rolling and recruitment in E-selectin and P-selectin double mutant mice. J Exp Med 1996;183:2329-2336.

19 Kunkel EJ, Ley K. Distinct phenotype of E-selectindeficient mice. E-selectin is required for slow leukocyte rolling in vivo. Circ Res 1996;79:1196-1204.

20 Ley K, Allietta M, Bullard DC, et al. Importance of E-selectin for firm leukocyte adhesion in vivo. Circ Res 1998;83:287-294.

21 Milstone DS, Fukumura D, Padgett RC, et al. Mice lacking E-selectin show normal numbers of rolling leukocytes but reduced leukocyte stable arrest on cytokine-activated microvascular endothelium. Microcirculation 1998;5:153-171.

22 Keelan ET, Harrison AA, Chapman PT, et al. Imaging vascular endothelial activation: an approach using radiolabeled monoclonal antibodies against the endothelial cell adhesion molecule E-selectin. J Nucl Med 1994;35:276-281.

23 Picker LJ, Kishimoto TK, Smith CW, et al. ELAM-1 is an adhesion molecule for skin-homing T cells. Nature 1991;349:796-799.

24 Lorant DE, Topham MK, Whatley RE, et al. Inflammatory roles of P-selectin. J Clin Invest 1993; 92:559-570. 
25 Butcher EC. Specificity of leukocyte-endothelial interactions and diapedesis: physiologic and therapeutic implications of an active decision process. Res Immunol 1993;144:695-698.

26 Wertheimer SJ, Myers CL, Wallace RW, et al. Intercellular adhesion molecule-1 gene expression in human endothelial cells. J Biol Chem 1992;267: 12030-12035.

27 Hulkower KI, Pollock JS, Walsh RE, et al. Leukotrienes do not regulate nitric oxide production in RAW 264.7 macrophages. Prostaglandins Leukot Essent Fatty Acids 1996;55:45-49.

28 Marotta P, Sautebin L, Di Rosa M. Modulation of the induction of nitric oxide synthase by eicosanoids in the murine macrophage cell line J774. Br J Pharmacol 1992;107:640-641.

29 Singh VP, Patil CS, Kulkarni SK. Effect of 5-lipoxygenase inhibition on events associated with inflammatory bowel disease in rats. Indian J Exp Biol 2004; 42:667-673.

30 Hendel J, Ahnfelt-Ronne I, Nielsen OH. Expression of 5 -lipoxygenase mRNA is unchanged in the colon of patients with active inflammatory bowel disease. Inflamm Res 2002;51:423-426.

31 Roberts WG, Simon TJ, Berlin RG, et al. Leukotrienes in ulcerative colitis: results of a multicenter trial of a leukotriene biosynthesis inhibitor, MK-591. Gastroenterology 1997;112:725-732.

32 Hawkey CJ, Dube LM, Rountree LV, et al. A trial of zileuton versus mesalazine or placebo in the maintenance of remission of ulcerative colitis. The European Zileuton Study Group For Ulcerative Colitis. Gastroenterology 1997;112:718-724.

33 Hillingso J, Kjeldsen J, Laursen LS, et al. Blockade of leukotriene production by a single oral dose of MK0591 in active ulcerative colitis. Clin Pharmacol Ther 1995;57:335-341.

34 Zingarelli B, Squadrito F, Graziani P, et al. Effects of zileuton, a new 5-lipoxygenase inhibitor, in experimentally induced colitis in rats. Agents Actions 1993;39:150-156.

35 Sturiale S, Barbara G, Qiu B, et al. Neutral endopeptidase (EC 3.4.24.11) terminates colitis by degrading substance P. Proc Natl Acad Sci USA 1999;96:1165311658.

36 Lora L, Mazzon E, Billington D, et al. Effects of cyclosporin A on paracellular and transcellular transport of horseradish peroxidase in perfused rat livers. Dig Dis Sci 1997;42:514-521.

37 Wallace JL, Keenan CM, Gale D, et al. Exacerbation of experimental colitis by non-steroidal antinflammatory drugs is not related to elevate leukotriene B4 synthesis. Gastroenterology 1992;102:18-27.

38 Miller MJ, Thompson JH, Zhang XJ, et al. Role of inducible nitric oxide synthase expression and peroxynitrite formation in guinea pig ileitis. Gastroenterology 1995;109:1475-1483.

39 Mullane KM, Kraemer R, Smith B. Myeloperoxidase activity as a quantitative assessment of neutrophil infiltration into ischemic myocardium. J Pharmacol Methods 1985;14:157-167.

40 Kayali ZAZ, Haddad W, Holmes EW, et al. Barrett differential effects of T-cell activation on gastric and small bowel permeability in alcohol-consuming mice. Alcohol Clin Exp Res 2002;26:1436-1443.

41 Lauredo IT, Sabater JR, Ahmed A, et al. Mechanism of pyocyanin- and 1-hydroxyphenazine-induced lung neutrophilia in sheep airways. J Appl Physiol 1998; 85:2298-2304.

42 La M, Cao TV, Cerchiaro G, et al. A novel biological activity for galectin-1 inhibition of leukocyte-endothelial cell interactions in experimental inflammation. Am J Pathol 2003;163:1505-1515.

43 Perretti M, Croxtall JD, Wheller SK, et al. Mobilizing lipocortin 1 in adherent human leukocytes downregulates their transmigration. Nat Med 1996;2:1259-1262.

44 Ford-Hutchinson AW, Bray MA, Doig MV, et al. Leukotriene B, a potent chemokinetic and aggregating substance released from polymorphonuclear leukocytes. Nature 1980;286:264.

45 Geng JG, Bevilacqua MP, Moore KL, et al. Rapid neutrophil adhesion to activated endothelium mediated by GMP-140. Nature 1990;343:757-760.

46 Lawrence MB, Spinger TA. Leukocytes roll on a selectin at physiologic flow rates: distinction from and prerequisite for adhesion through integrins. Cell 1991;65:859-873.

47 Davenpeck KL, Gauthier TW, Albertine KH, et al. Role of P-selectin in microvascular leukocyte-endothelial interaction in splanchnic ischemia-reperfusion. Am J Physiol 1994;267:H622-H630.

48 Farhood A, McGuire GM, Manning AM, et al. Intercellular adhesion molecule 1 (ICAM-1) expression and its role in neutrophil-induced ischemia-reperfusion injury in rat liver. J Leukoc Biol 1995;57:368-374.

49 Shreeniwas R, Koga S, Karakurum M, et al. Hypoxiamediated induction of endothelial cell interleukin-1 alpha. An autocrine mechanism promoting expression of leukocyte adhesion molecules on the vessel surface. J Clin Invest 1992;90:2333-2339.

50 Luscinskas FW, Ding H, Lichtman AH. P-selectin and vascular cell adhesion molecule 1 mediate rolling and arrest, respectively, of CD4+ T lymphocytes on tumor necrosis factor alpha-activated vascular endothelium under flow. J Exp Med 1995;181:1179-1186.

51 Clark WM, Lauten JD, Lessov N, et al. Time course of ICAM-1 expression and leukocyte subset infiltration in rat forebrain ischemia. Mol Chem Neuropathol 1995;26:213-230.

52 Horie Y, Wolf R, Iyasaka M, et al. Leukocyte adhesion and hepatic microvascular responses to intestinal ischemia/reperfusion in rats. Gastroenterology 1996; 111:666-673.

53 Gauthier TW, Davenpeck KL, Lefer AM. Nitric oxide attenuates leukocyte-endothelial interaction via $\mathrm{P}$ selectin in splanchnic ischemia-reperfusion. Am J Physiol 1994;267:G562-G568.

54 Hawkins HK, Entman ML, Zhu JY, et al. Acute inflammatory reaction after myocardial ischemic injury and reperfusion. Development and use of a neutrophilspecific antibody. Am J Pathol 1996;148:1957-1969.

55 Furie MB, Tancinco MC, Smith CW. Monoclonal antibodies to leukocyte integrins CD11a/CD18 and CD11b/CD18 or intercellular adhesion molecule-1 inhibit chemoattractant-stimulated neutrophil transendothelial migration in vitro. Blood 1991;78:2089-2097.

56 Kukielka GL, Youker KA, Hawkins HK, et al. Regulation of ICAM-1 and IL-6 in myocardial ischemia: effect of reperfusion. Ann NY Acad Sci 1994;723:258-270.

57 Byrum RS, Goulet JL, Snouwaert JN, et al. Determination of the contribution of cysteinyl leukotrienes and leukotriene $\mathrm{B}_{4}$ in acute inflammatory responses using 5-lipoxygenase- and leukotriene $\mathrm{A}_{4}$ hydrolase-deficient mice. J Immunol 1999;163:6810. 
58 Byrum RS, Goulet JL, Griffiths RJ, et al. Role of the 5lipoxygenase-activating protein (FLAP) in murine acute inflammatory responses. J Exp Med 1997;185:1065.

59 Laursen LS, Naesdal J, Bukhave K, et al. Selective 5-lipoxygenase inhibition in ulcerative colitis. Lancet 1990;35:683-685.

60 Bertran X, Mane J, Fernandez-Banares F, et al. Intracolonic administration of zileuton, a selective 5 -lipoxygenase inhibitor, accelerates healing in a rat model of chronic colitis. Gut 1996;8:899-904.

61 Holma R, Salmenpera P, Riutta A, et al. Acute effects of the cys-leukotriene-1 receptor antagonist, montelukast, on experimental colitis in rats. Eur J Pharmacol 2001;29:309-318.

62 Wallace JL, MacNaughton WK, Morris GP, et al. Inhibition of leukotriene synthesis markedly accelerates healing in a rat model of inflammatory bowel disease. Gastroenterology 1989;96:29-36.

63 Hollander D. Intestinal permeability, leaky gut, and intestinal disorders. Curr Gastroenterol Rep 1999;1: 410-416.

64 Bjarnason I, Maxton D, Reynolds AP, et al. Comparison of four markers of intestinal permeability in control subjects and patients with coeliac disease. Scand J Gastroenterol 1994;29:630-639.

65 Jenkins RT, Jones DB, Goodacre RL, et al. Reversibility of increased intestinal permeability to 51Cr-EDTA in patients with gastrointestinal inflammatory diseases. Am J Gastroenterol 1987;82:1159-1164.

66 Zhang Y, Lee B, Thompson $\mathrm{M}$, et al. Lactulosemannitol intestinal permeability test in children with diarrhea caused by rotavirus and cryptosporidium. Diarrhea Working Group, Peru J Pediatr Gastroenterol Nutr 2000;31:16-21.
67 Alam AN, Sarker SA, Wahed MA, et al. Enteric protein loss and intestinal permeability changes in children during acute shigellosis and after recovery: effect of zinc supplementation. Gut 1994;35:1707-1711.

68 Zuckerman MJ, Watts MT, Bhatt BD, et al. Intestinal permeability to $\left[{ }^{51} \mathrm{Cr}\right] \mathrm{EDTA}$ in infectious diarrhea. Dig Dis Sci 1993;38:1651-1657.

69 Schrander JJ, Unsalan-Hooyen RW, Forget PP, et al. $\left[{ }^{51} \mathrm{Cr}\right]$ EDTA intestinal permeability in children with cow's milk intolerance. J Pediatr Gastroenterol Nutr 1990;10:189-192.

70 Ukabam SO, Mann RJ, Cooper BT. Small intestinal permeability to sugars in patients with atopic eczema. Br J Dermatol 1984;110:649-652.

71 Bjarnason I, MacPherson A, Hollander D. Intestinal permeability: an overview. Gastroenterology 1995;108:1566-1581.

72 Juby LD, Rothwell J, Axon AT. Lactulose/mannitol test: an ideal screen for celiac disease. Gastroenterology 1989;96:79-85.

73 Vogelsang H, Genser D, Wyatt J, et al. Screening for celiac disease: a prospective study on the value of noninvasive tests. Am J Gastroenterol 1995;90:394-398.

74 Hamilton I, Cobden I, Rothwell J, et al. Intestinal permeability in coeliac disease: the response to gluten withdrawal and single-dose gluten challenge. Gut 1982;23:202-210.

75 Wyatt J, Vogelsang $\mathrm{H}$, Hubl W, et al. Intestinal permeability and the prediction of relapse in Crohn's disease. Lancet 1993;341:1437-1439.

76 D'Inca R, Di Leo V, Corrao G, et al. Intestinal permeability test as a predictor of clinical course in Crohn's disease. Am J Gastroenterol 1999;94:29562960. 